\title{
The CD59 Family Member Leaky/Coiled Is Required for the Establishment of the Blood-Brain Barrier in Drosophila
}

\author{
Mubarak Hussain Syed, ${ }^{\star}$ Alice Krudewig, ${ }^{\star}$ Daniel Engelen, Tobias Stork, and Christian Klämbt \\ Institut für Neurobiologie, Universität Münster, D-48149 Münster, Germany
}

The blood- brain barrier of Drosophila is established by the subperineurial glial cells that encase the CNS and PNS. The subperineurial glial cells are thin, highly interdigitated cells with epithelial character. The establishment of extensive septate junctions between these cells is crucial for the prevention of uncontrolled paracellular leakage of ions and solutes from the hemolymph into the nervous system. In the absence of septate junctions, macromolecules such as fluorescently labeled dextran can easily cross the blood-brain barrier. To identify additional components of the blood- brain barrier, we followed a genetic approach and injected Texas-Red-conjugated dextran into the hemolymph of embryos homozygous for chromosomal deficiencies. In this way, we identified the 153-aa-large protein Coiled, a new member of the Ly6 (leukocyte antigen 6) family, as being crucially required for septate junction formation and blood-brain barrier integrity. In coiled mutants, the normal distribution of septate junction markers such as NeurexinIV, Coracle, or Discs large is disturbed. EM analyses demonstrated that Coiled is required for the formation of septate junctions. We further show that Coiled is expressed by the subsperineurial glial cells in which it is anchored to the cell membrane via a glycosylphosphatidylinositol anchor and mediates adhesive properties. Clonal rescue studies indicate that the presence of Coiled is required symmetrically on both cells engaged in septate junction formation.

\section{Introduction}

The functionality of neuronal networks primarily depends on the precise regulation of ion concentrations in their environment. The nervous system therefore requires its efficient insulation from circulating blood or hemolymph systems. In consequence, in higher organisms, a blood-brain barrier (BBB) actively ensures a constant ionic environment needed for reliable neuronal function (Carlson et al., 2000; Daneman and Barres, 2005; Abbott et al., 2006; Banerjee and Bhat, 2007; Zlokovic, 2008).

In invertebrates, the BBB is brought about by glial cells, and, despite many differences in the organization of the nervous system in invertebrates and vertebrates, many functional properties are evolutionary conserved. Drosophila provides a number of ex-

Received Feb. 11, 2011; revised March 21, 2011; accepted April 9, 2011.

Author contributions: C.K. designed research; M.H.S., A.K., D.E., and T.S. performed research; M.H.S., A.K., and T.S. analyzed data; C.K. wrote the paper.

${ }^{*}$ M.H.S. and A.K. contributed equally to this work.

This work has been supported by European Community Seventh Framework Programme FP7/2007-2013 under Grant Agreement HEALTH-F2-2008-201535 (C.K.). M.H.S. acknowledges a fellowship from the Graduate School of Cell Dynamics and Disease (University of Münster, Münster, Germany). We thank R. Fehon for providing anti-Coracle antibodies. Additional antibodies were obtained from the Developmental Studies Hybridoma Bank (University of lowa, lowa (ity, IA), and all general fly stocks were provided by the Bloomington Drosophila Stock Center (Bloomington, IN). We thank the Flyprot consortium for providing a GFP- exon insertion in the coiled gene. We are grateful to R. Stephan for comments on this manuscript and help during the entire project, Alex Grimm for help with the transposon excision experiment, and H. Aberle, S. Bogdan, P. Kain, and all members of the Klämbt laboratory for help and advice in different phases of the project.

Correspondence should be addressed to Christian Klämbt, Institut für Neurobiologie, Universität Münster, Badestrasse 9, D-48149 Münster, Germany. E-mail: klaembt@uni-muenster.de.

A. Krudewig's present address: Biozentrum, University of Basel, Klingelbergstrasse 70, CH-4056 Basel, Switzerland.

T. Stork's present address: University of Massachusetts Medical School, Department of Neurobiology, 362 Plantation Street, LRB 740, Worcester, MA 01605.

DOI:10.1523/JNEUROSCI.0766-11.2011

Copyright $\odot 2011$ the authors $\quad 0270-6474 / 11 / 317876-10 \$ 15.00 / 0$ perimental advantages to study the BBB formation and function (Edenfeld et al., 2005; Edwards and Meinertzhagen, 2010). A variety of glial subtypes have been identified in Drosophila, and many tools to visualize and manipulate them have been developed (Klämbt and Goodman, 1991; Ito et al., 1995; YounossiHartenstein et al., 2003; Pereanu et al., 2005; Schwabe et al., 2005; Silies et al., 2007; Awasaki et al., 2008; Stork et al., 2008). The insect nervous system is surrounded by hemolymph with a high potassium concentration of $\sim 50 \mathrm{~mm}$ (Krans et al., 2010). Perineurial and subperineurial glial (SPG) cells, which also express unidirectionally acting xenobiotic transporters, provide the cellular basis of the BBB (Bainton et al., 2005; Schwabe et al., 2005; Stork et al., 2008; Mayer et al., 2009). In particular, the extensively interdigitating subperineurial glial cells seal the nervous system by forming septate junctions, which mediate a tight cellular contact that prevents uncontrolled paracellular leakage of solutes from the hemolymph into the nervous system (Carlson et al., 2000). Although the organization of septate junctions has been well characterized by EM analysis, almost nothing is known how this intricate structure develops and how its final barrier function is set up.

The notion that the molecular principles underlying glial differentiation are conserved between the mammalian and the Drosophila nervous system was also supported by recent work on the molecular components of septate junctions in Drosophila and septate-like junctions at the paranode of myelinating glia cells in vertebrates (Baumgartner et al., 1996; Bhat et al., 2001; Girault and Peles, 2002; Poliak and Peles, 2003; Faivre-Sarrailh et al., 2004; Banerjee et al., 2006b; Salzer et al., 2008). Mutants lacking septate junctions between the subperineurial glia show paracellular leakage of potassium into the nervous system (Auld et al., 1995; 

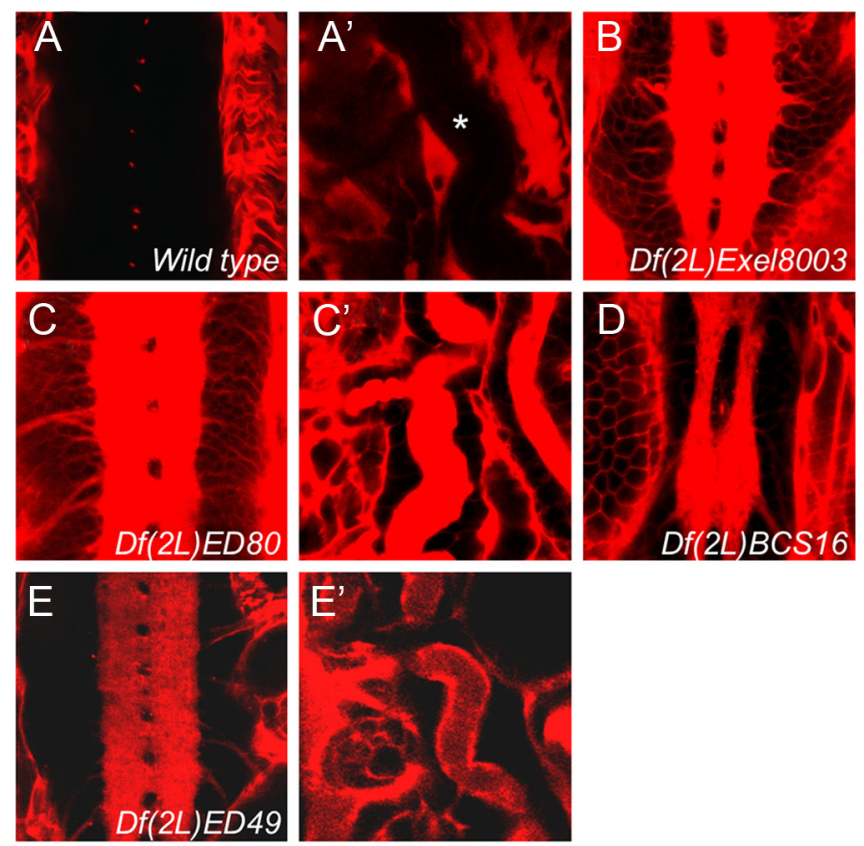

Figure 1. Identification of coiled. Ten kilodalton Texas-Red-labeled dextran was injected into stage 17 embryos of the genotypes indicated. Homozygous mutant embryos were identified using GFP-labeled balancer chromosomes. $\boldsymbol{A}-\boldsymbol{E}$, Frontal views of ventral nerve cords or trachea $\left(\boldsymbol{A}^{\prime}-\boldsymbol{E}^{\prime}\right)$. $\boldsymbol{A}$, No penetration of fluorescently labeled dextran was observed into the nerve cord of stage 17 wild-type embryos. $\boldsymbol{B}-\boldsymbol{E}$, Fluorescently labeled dextran penetrates into the ventral nerve cord of embryos homozygous for several different chromosomal deficiencies. The trachea in mutant embryos show a convoluted phenotype and are leaky.

Baumgartner et al., 1996; Schulte et al., 2003; Stork et al., 2008). Moreover, a reduction of septate junction length, as can be seen in Drosophila moody mutants, impairs BBB function (Bainton et al., 2005; Schwabe et al., 2005). To further decipher the molecular components required for a functional BBB in Drosophila, we performed a genetic screen and uncovered the coiled gene, which encodes a small glycosylphosphatidylinositol (GPI)-linked protein of the Ly6 (leukocyte antigen 6)/CD59 family. Coiled is secreted to the cell surface, where it mediates cell adhesion. Clonal analysis demonstrates that Coiled is required in two neighboring cells to ensure the correct distribution of septate junction proteins.

\section{Materials and Methods}

Molecular genetics, fly work, and cell culture. To generate a UAScoiled construct, we subcloned the coiled cDNA (LD16147) into pUAST and generated several transgenic strains. For cloning, we used the gateway system. Constructs encoding the different tagged Coiled proteins were synthesized by Genescript. The N-terminal HA tag is placed at position 27, just after the signal sequence, and the C-terminal HA tag is placed at amino acid position 123, a single residue before the GPI attachment site (see Fig. 3). All constructs were sequenced for verification. Transgenic Drosophila strains were generated using phiC31-based transformation according to standard procedures (Bischof et al., 2007). Tissue culture experiments were performed as described (Stork et al., 2009). Phosphatidylinositol-specific phospholipase C (PI-PLC) experiments were performed as described (Koh et al., 2008). The insertion of a GFP exon in the coiled gene is determined by the Flyprot consortium (http:// www.flyprot.org). The coiled in situ expression data were determined by Berkeley Drosophila Genome Project and are available at http://www. fruitfly.org/cgi-bin/ex/insitu.pl.

Immunohistochemistry and electron microscopic analysis. Fixation and treatment of tissues for immunohistochemistry was performed as described (Stork et al., 2008). Fluorescently labeled specimens were analyzed using a Carl Zeiss 710 LSM, and orthogonal sections were taken using the Zen software of Carl Zeiss. For electron microscopic analysis, embryos were fixed in glutaraldehyde saturated $n$-heptane, and the
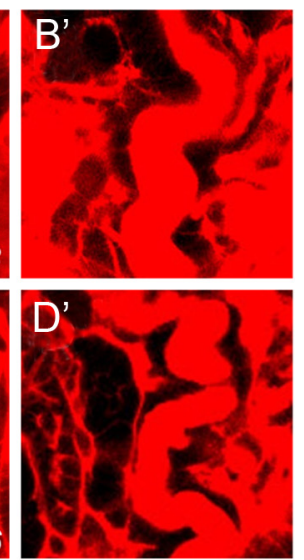

vitelline membrane was removed by hand. After a simultaneous fixation in glutaraldehyde and $\mathrm{OsO}_{4}$, tissues were embedded in Epon as described (Stork et al., 2008). Ultrathin sections were viewed with a Carl Zeiss 900 TEM.

Dextran uptake. Dextran solutions were injected into stage 17 embryos as described previously (Stork et al., 2008). The kinetics were determined on a Carl Zeiss LSM 710. Z-stacks through the entire ventral nerve cord were recorded. The mean intensity in neuropil region of six neuromers was determined in at least four animals per genotype. The genotype of the embryos was determined using GFP-labeled balancer chromosomes. The laser settings were identical throughout the experiments.

\section{Results}

\section{Identification of coiled}

To identify additional proteins that are required for the establishment of the blood-brain barrier, we injected fluorescently labeled dextran into the body cavity of stage 17 embryos homozygous for chromosomal deficiencies (Fig. 1). The diffusion of fluorescent dye into the CNS was monitored using confocal microscopy. Although wild-type embryos are able to exclude the dye from the CNS, animals with an impaired BBB show dye penetration into the brain (Bainton et al., 2005; Schwabe et al., 2005; Stork et al., 2008). The injected embryos were then screened for those with a defective blood-brain barrier. From this screen, we identified the deficiency $D f(2 L) E D 49$, which in homozygosis resulted in a leaky blood-brain barrier (Fig. 1A,E). In addition, we noted dye uptake into trachea, which showed a convoluted phenotype, as it is often found in mutants affecting septate junctions (Fig. 1 $A^{\prime}-E^{\prime}$ ) (Wu and Beitel, 2004; Wu et al., 2004, 2007; Bachmann et al., 2008; Laprise et al., 2009, 2010).

Thus, we concluded that $D f(2 L) E D 49$ uncovered a gene required for epithelial barrier formation. This notion is supported by the finding that additional deficiencies overlapping the genomic region deleted in $D f(2 L) E D 49$ lead to identical dye penetration phenotypes $[D f(2 L)$ Excel8003; $D f(2 L) B C S 16 ; D f(2 L) E D 80]$ (Fig. $1 B-D$ ). According to the genome annotation (Dowell et al., 2001; Tweedie et al., 2009), the deficiency $D f(2 L) E D 49$ removes only seven transcription units, and the function of five of these transcription units can be tested by additional alleles (Fig. $1 E$ ) (see Fig. 3A-E) (Hahn and Jackle, 1996; Royet et al., 1998). Of the five mutants tested, only a transposon insertion into the second coding exon of CG2813 PBac[f05607] (abbreviated as coiled ${ }^{P}$ ) displayed a dye penetration phenotype in homozygosis and in trans to the deficiency $D f(2 L) E D 49$ (Figs. $2 D-F, 3 D$ ). The lethality and the dye penetration phenotype associated with the transposon insertion can be reverted by precise excision (data not shown). Based on its mutant phenotype, we originally termed the gene leaky. Recently, the same gene has been named coiled (cold) (Nilton et al., 2010).

To characterize the blood-brain barrier defects observed in coiled mutants in more detail, we compared the dye penetration characteristics of coiled mutant animals with other mutants known to affect the blood-brain barrier (Fig. 2). neurexinIV mutant animals do not form septate junctions and have a permeable 

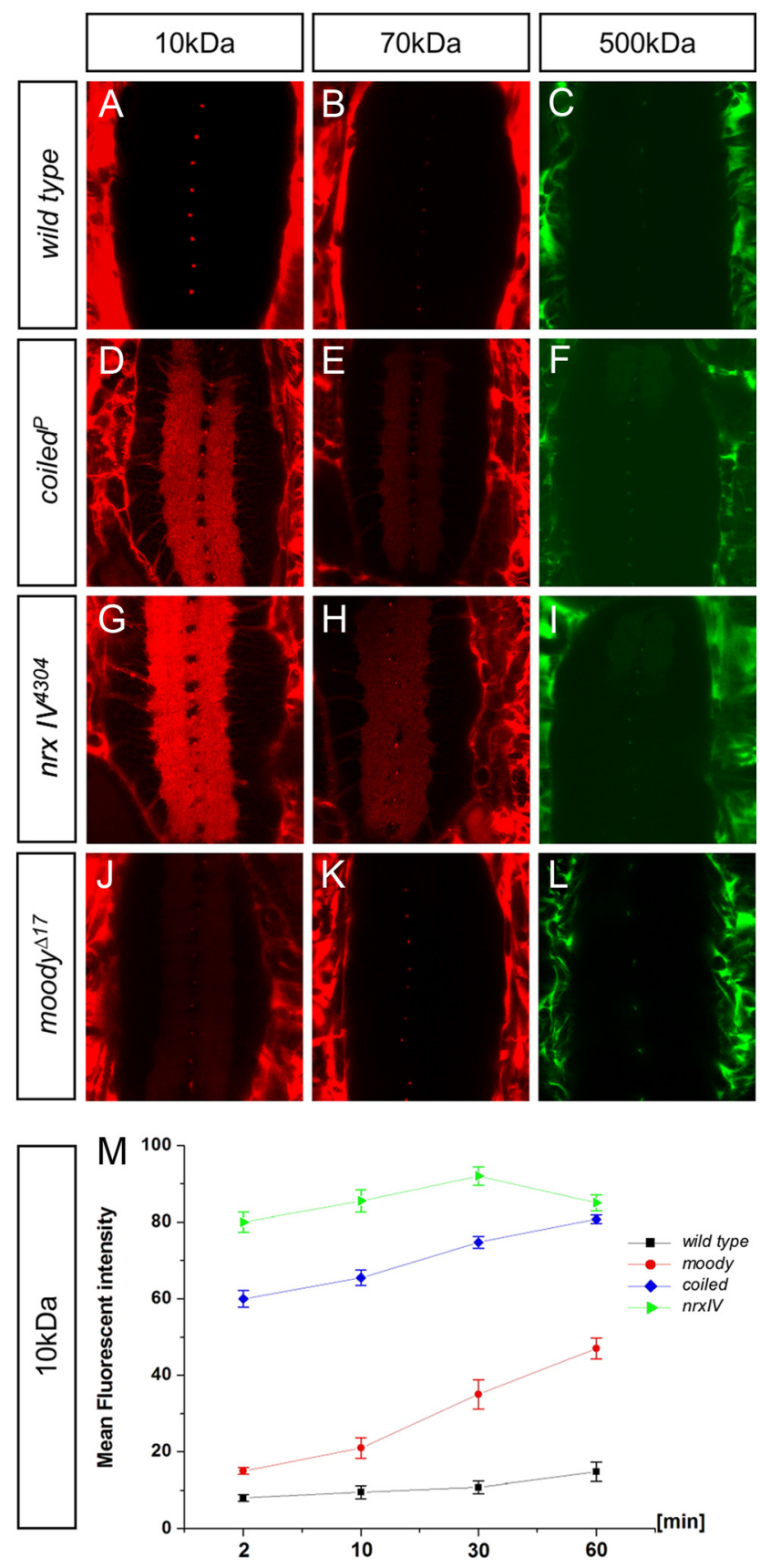

Figure 2. coiled mutants show similar BBB defects as neurexin/V mutants. Differently sized fluorescent-labeled dextran molecules were injected into stage 17 embryos of the following

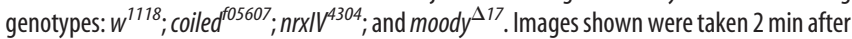
injection. The different sized dextrans are indicated; all images were taken with a Carl Zeiss LSM 710 microscope. Homozygous embryos were recognized using GFP-labeled balancer chromosomes. $\boldsymbol{A}-\boldsymbol{C}, \mathbf{A} w^{1118}$ embryo is used as wild-type control. $\boldsymbol{D}-\boldsymbol{F}$, In coiled mutants, smaller dyes readily penetrated into the nerve cord. Larger dyes penetrate into the nerve cord but not as easily as the $10 \mathrm{kDa}$ dextran. $\mathbf{G}-\mathbf{I}$, In neurexin/V (nrx/V) mutant embryos, all sizes of dextran molecules penetrated comparable with coiled mutants. $J-L$, Dye penetration in moody mutants. M, Quantification of $10 \mathrm{kDa}$ dextran uptake over $60 \mathrm{~min}$ in the genotypes indicated.

blood-brain barrier (Baumgartner et al., 1996; Stork et al., 2008). In contrast, homozygous moody mutants show reduced septate junctions and have a mildly affected blood-brain barrier (Bainton et al., 2005; Schwabe et al., 2005). The barrier defects can be assessed by the kinetics of dye penetration and by determining the penetration of differently sized dextrans (Stork et al., 2008).
In these assays, coiled animals are characterized by very similar, although somewhat less pronounced, permeability to highmolecular-weight dyes compared with neurexinIV mutants (Fig. 2). In neurexinIV mutants, 10,70 , and $500 \mathrm{kDa}$ labeled dextran molecules can easily penetrate into the CNS. Similar penetration defects are observed in coiled mutant animals (Fig. 2D-I). In contrast, moody mutants only show a clear penetration defect for $10 \mathrm{kDa}$ labeled dextran, whereas relatively little penetration is noted for larger dextran molecules (Fig. $2 J-L$ ). The similarity of the coiled and the neurexinIV mutant phenotypes became even more evident when we compared the kinetics of dye uptake by determining the increase of fluorescence intensity in the CNS over $1 \mathrm{~h}$ (Fig. $2 \mathrm{M}$ ). Together, these data point to a strong impairment of the blood-brain barrier in coiled mutants.

\section{The coiled gene}

The coiled gene generates a small transcript from three exons and encodes a 153-aa-long protein with a predicted molecular weight of $\sim 15 \mathrm{kDa}$. The presence of a signal sequence, which is encoded in the first exon, suggests that the protein is transported to the secretory pathway. Additional structural motives suggest that Coiled is tethered to the membrane by a GPI anchor (Fig. 3F) (see below). Position-specific iterated BLAST searches identified Coiled as a member of the Ly6/CD59 protein family (Nilton et al., 2010). Within the Drosophila genome, a large number of Ly6/ CD59-like proteins have been described (Hijazi et al., 2009). The most closely related protein is Boudin, which is required for the formation of septate junctions in the developing tracheal system (Hijazi et al., 2009). To address where coiled is expressed, we performed in situ hybridization experiments and generated several antibodies directed against different peptides derived from the Coiled protein. Unfortunately, none of the Coiled antibodies allows detection of the endogenous Coiled protein in fixed specimens. The mRNA is expressed in tissues that form septate junctions (embryonic hindgut, trachea, epidermis, and the dorsal pouch). Faint expression can also be detected in the nervous system (Berkeley Drosophila Genome Project) (Tomancak et al., 2007) (data not shown).

To further determine the Coiled expression pattern, we used the GFP-exon trap insertion $C P T I^{001277}$ located in the first intron (Fig. 3A). The GFP-exon is spliced in frame and generates an $\mathrm{N}$-terminally tagged Coiled protein. This protein variant, however, appears nonfunctional, and homozygous $C P T I^{001277}$ flies die during embryonic development. During embryonic development, this Coiled fusion protein is expressed by all septate-junctionforming tissues. In the nervous system, Coiled is expressed by all subperineurial glial, cells that form the blood-brain barrier. Likewise, Coiled is specifically expressed by the subperineurial glial cells during larval and adult stages (Fig. $4 A-E$ ). Within the subperineurial glia, elevated levels can be detected at the cell-cell junction (Fig. 4C, arrows).

\section{Coiled is required for septate junction formation in the subperineurial glia}

The coiled mutant phenotype is characterized by a defective blood-brain barrier. The overall organization of the nervous system as well as the distribution of all glial cells, however, appeared normal (Fig. $4 F-K$ ). To further determine whether abnormal septate junctions between the subperineurial glial cells could account for the disrupted barrier function in coiled mutants, we determined the ultrastructural phenotype using transmission electron microscopic analysis. In wild-type stage 17 embryos, subperineurial glial cells are characterized by extensive septate 
A

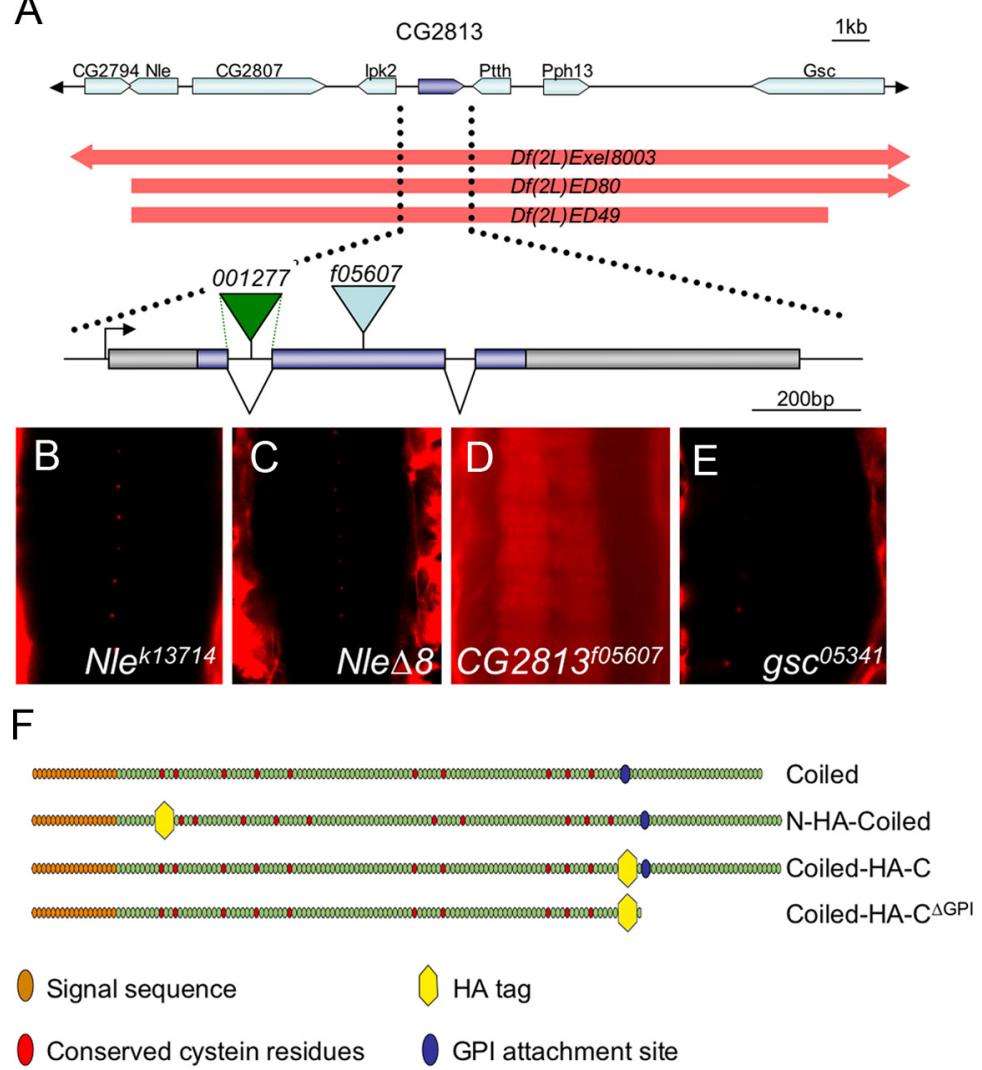

Figure 3. Genomic region of coiled. $\boldsymbol{A}$, Schematic view of the genomic region encompassing the coiled gene. The location and orientation of eight genes is depicted by arrows. The extent of three deficiencies is indicated. The Df(2L)ED49 affects seven transcription units (Nle, (G2807, Ipk2, (G2813, Ptth, Pph13, and gsc) in the region 21E2. The function of five of these genes can be addressed using specific mutants (Flybase). The exon-intron structure of coiled and the integration sites of the transposon insertions used in this study are indicated. $\boldsymbol{B}-\boldsymbol{E}$, Ventral views of ventral nerve cords of the genotypes indicated. Only homozygous C $G 2813^{f 05607}$ embryos show a disrupted blood-brain barrier, and fluorescently labeled dextran penetrates into the nervous system (D). $\boldsymbol{F}$, Schematic organization of the four different Coiled constructs used in this study.

junctions (Fig. 5A,B) (Tepass and Hartenstein, 1994). Homozygous mutant stage 17 embryos, which were selected with the help of GFP-expressing balancer chromosomes, lack septae between subperineurial glial cells, explaining the disrupted blood-brain barrier (Fig. 5C,D). To better understand the disruption of septate junctions observed in coiled mutants, we analyzed the distribution of wellcharacterized septate junction components: NeurexinIV, Coracle, Discs large, and Fasciclin III. In epithelial tissues such as the epidermis and the hindgut, these proteins are associated with septate junctions and prominently localize to a region in the apical part of the basolateral membrane (Woods and Bryant, 1991; Baumgartner et al., 1996; Lamb et al., 1998; Wu and Beitel, 2004) (Figs. 6, 7). In contrast, coiled mutants show a mislocalization of these septatejunction-associated proteins along the entire basolateral membrane domain (Fig. 6). In conclusion, these data show that coiled is required for the establishment of septate junctions.

\section{Coiled acts cell autonomously to control blood-brain barrier integrity}

To further verify that the Coiled protein is required for the bloodbrain barrier formation, we performed rescue experiments using the Gal4/UAS system. We generated UAS constructs that allow the expression of wild-type as well as $\mathrm{N}$ - and C-terminally tagged Coiled protein variants (Fig. $3 F$ ). After integration of these constructs in the same chromosomal landing site $(86 \mathrm{Fb})$ using phiC31-mediated in- tegration, we confirmed similar expression strength by Western blot analyses (Bischof et al., 2007) (see Fig. 9).

During daughterlessGal4-driven ubiquitous expression of UAScoiled in coiled mutants, lethality was rescued and fluorescently labeled dextran was not able to cross the blood-brain barrier (data not shown). Because the closely related Ly6 member Boudin acts in a non-autonomous manner (Hijazi et al., 2009), we next examined the autonomy of coiled function. When we expressed untagged or C-terminally tagged Coiled protein in the engrailed pattern, we noted a rescue of septate junction assembly in all engrailedexpressing cells (Fig. 7) (data not shown). In a wild-type hindgut, NeurexinIV or Coracle is strictly localized to a short apical stretch of the lateral cell membrane (Figs. 6, 7A). In coiled mutants, expression spreads uniformly around the basolateral membrane domain. During engrailed directed expression of a C-terminally tagged Coiled protein in a mutant coiled background, NeurexinIV and Coracle recruitment to a short stretch of the lateral cell membrane is restored only within the engrailed domain (Fig. $7 B, D$ ).

In contrast, expression of an $\mathrm{N}$ terminally tagged Coiled protein is not able to rescue the lethality associated with coiled mutants and does not change the NeurexinIV or Coracle expression defects, although both proteins are expressed from the same chromosomal location. Likewise, the GFP-tagged Coiled protein variant generated in the exon trap line $C P T I^{001277}$ appears nonfunctional, and homozygous $C P T I^{001277}$ flies as well as $C P T I^{001277} / D f(2 L) E D 49$ are lethal.

In a next step, we expressed coiled in a pan-glial manner (using repoGal4) to ask whether coiled acts cell autonomously within the blood-brain barrier. This expression paradigm does not rescue the lethal phenotype associated with coiled but completely restores blood-brain barrier integrity of coiled mutants (Fig. 7G). Expression in neurons driven by elavGal4 rescues neither the blood-brain barrier integrity nor the lethality (data not shown). Thus, Coiled appears to act cell autonomously to control the formation of septate junctions.

\section{Septate junction formation requires symmetric \\ Coiled expression}

Septate junctions connect two neighboring cells. Both cells involved express a large number of proteins, which need to be correctly assembled in septate junctions. We wondered whether Coiled is required on both neighboring cells or whether expression in one cell would be sufficient to trigger septate junction formation. To test this, we expressed Coiled together with cytoplasmic GFP in a striped pattern in the epidermis using the engrailed-Gal4 driver (Fig. 7, en $\gg$ coiled). We determined the expression of Coracle and NeurexinIV along membranes that are flanked by two GFP-and thus Coiled-expressing cells (Fig. $8 \mathrm{~A}$, 
hexagon). The apicobasal length of the expression domain of septate junction markers such as Coracle or NeurexinIV within the engrailed stripe was compared with the length of the Coracle or NeurexinIV expression domain between one Coiledexpressing and one coiled mutant cell (Fig. $8 A$, oval) or to the situation as seen in the entirely mutant tissue (Fig. 8 , square). In each case, the relative length of the expression domain was determined in an orthogonal section and 60 cells were quantified in each instance (Fig. $8 B$ ). Only when Coiled function is present on both flanking cells is the normal localization of Coracle and NeurexinIV reestablished. In contrast, when Coiled is present only on one cell, Coracle and NeurexinIV distributes along the whole basolateral membrane as seen in entirely mutant tissue. Moreover, the expression of Coracle appears enhanced within the engrailed domain, which may be attributable to enhanced stabilization within the forming septate junctions. In summary, these data suggest that Coiled is required on both contacting cells to establish septate junctions.

\section{Coiled is a cell surface protein that can} mediate adhesion

To achieve its cell-autonomous function, Coiled could be either acting directly on the cell surface or it could be required to help trafficking of essential septate junction components as suggested recently (Nilton et al., 2010). To test this, we used cell aggregation assays. We transfected untagged and tagged Coiled constructs into Schneider 2 cells (S2 cells). Unlike wild-type S2 cells, which did not form any cell aggregates, cells expressing a C-terminally tagged Coiled protein formed small cell aggregates comprising up to 20 cells (Fig. 9A). Cells expressing the Nterminally tagged Coiled protein never showed any cell aggregates (Fig. 9B).

The aggregation experiments would be compatible with the notion that Coiled is a cell-surface protein tethered to the plasma membrane by a GPI anchor. To address this model, we transfected S2 cells with C-terminally tagged Coiled and subsequently treated the cells with PI-PLC. PI-PLC efficiently cleaves the GPI anchor and releases all GPI-anchored proteins into the medium (Volwerk et al., 1989). Without addition of PI-PLC, all Coiled protein is found in the cell lysate but is never found in the medium (Fig. 9C). During treatment with PI-PLC, a significant portion, but not all, of the Coiled protein is released to the medium. This result demonstrates that Coiled is a cell-surface protein in which it is most likely attached to the plasma membrane via a GPI anchor. At the plasma membrane, Coiled can act as a homophilic adhesion protein, which is likely to directly participate in septate junction assembly.
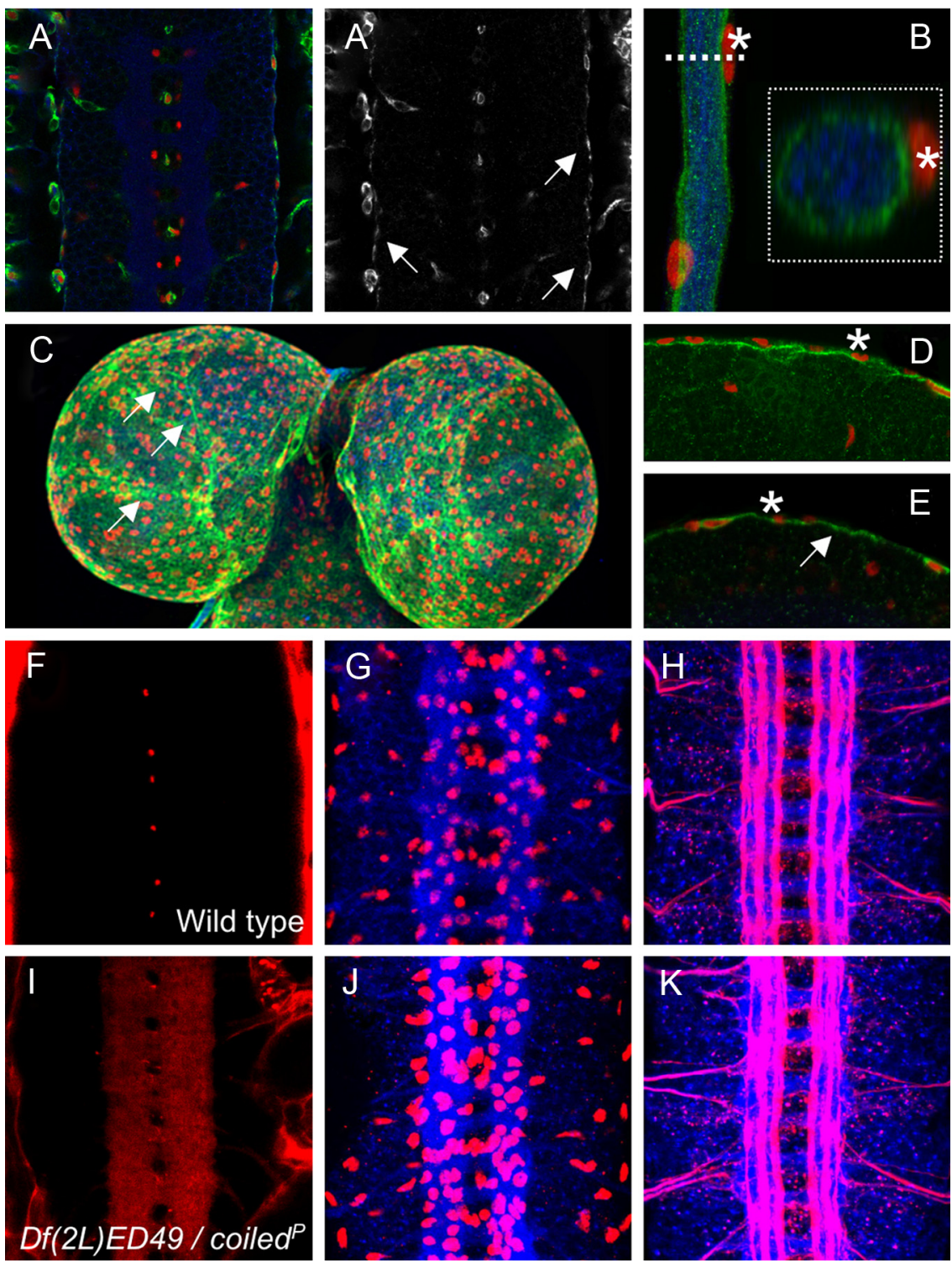

Figure 4. coiled does not affect overall CNS morphology. $A, A^{\prime}$, Ventral nerve cord of a stage 16 CPT/001277 embryo carrying a GFP exon in the first intron of Coiled. GFP expression is shown in green, HRP expression to label all neuronal membranes is shown in blue, and glial nuclei are labeled by Repo staining in red. $\boldsymbol{A}^{\prime}$, GFP-Coiled expression. Coiled is expressed in the outer glial cells layer in the subperineurial glial cells (arrows). The GFP-Coiled protein accumulates in the cytoplasm and is not secreted into the extracellular space. $\boldsymbol{B}$, Segmental nerve of a third-instar larva. GFP-Coiled is expressed by the subperineurial glia, which encircles the nerve. The nuclei abutting the GFP the subperineurial glia (asterisk) are nuclei of the perineurial glia. The boxed area is an orthogonal section taken at the level of the dashed line. C, Brain lobes of a third-instar larvae. Projection of a Z-stack. GFP expression is found in the subperineurial glia. Increased expression is noted at the cell boundaries (arrows). D, Single section showing expression in the subperineurial glia in the larval brain. The asterisks denote perineurial glia. $\boldsymbol{E}$, Single section showing expression on the subperineurial glia in the adult brain (arrow). $\boldsymbol{F}, \boldsymbol{I}$, Frontal views on stage 17 nerve cords in live embryos. $\mathbf{G}, \boldsymbol{H}, \mathbf{J}, \boldsymbol{K}$, Frontal views on dissected stage 16 nerve cords stained for neuronal membranes (blue, anti-HRP staining), Repo expression (G,J, red), and Fasciclin2 expression $(\boldsymbol{H}, \boldsymbol{K}$, red). $\boldsymbol{F}$, Wild-type stage 17 embryo injected with $10 \mathrm{kDa}$ labeled dextran. No dye penetrates into the ventral nerve cord. $\mathbf{G}, \boldsymbol{H}$, Wild-type stage 16 embryos, showing normal pattern of glial cells and CNS axon tracts. $\boldsymbol{I}$, Mutant coiled stage 17 embryo injected with $10 \mathrm{kD}$ a labeled dextran. The dye penetrates into the nerve cord. $\boldsymbol{J}, \boldsymbol{K}$, Mutant coiled stage 16 embryos. Glial cell number and overall axon pattern are normal.

\section{Coiled localizes to cell junctions in the subperineurial} glial cells

In the next step, we analyzed expression of the Coiled protein in tissues. Unfortunately, we failed generating functional anti-Coiled antisera. In addition, the GFP-tagged Coiled protein in the exon trap strain is nonfunctional and accumulates in the cytoplasm. We therefore stained for expression of the HA tag in the different UAS-Coiled constructs after Gal4-mediated expression. Expression of a C-termi- 

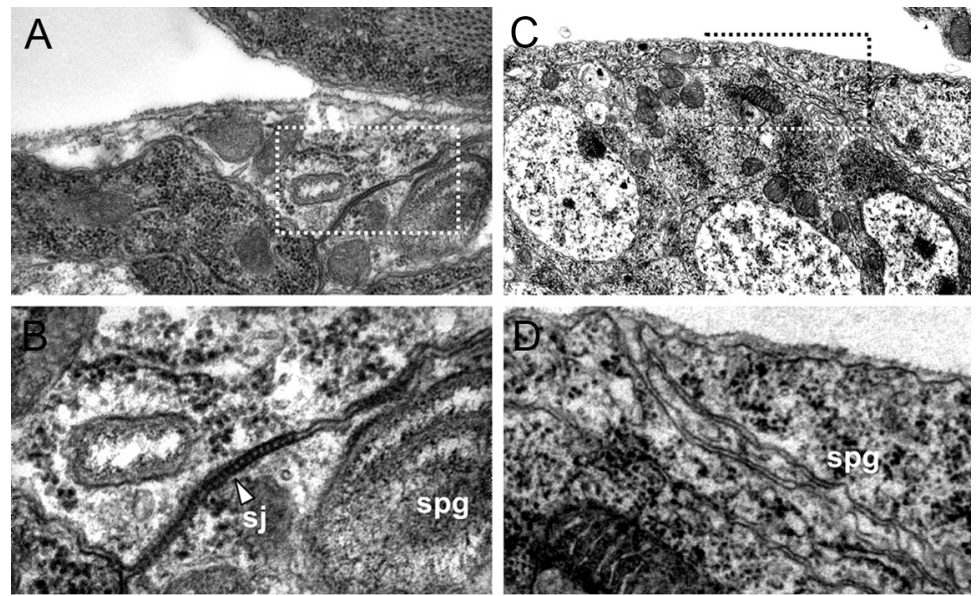

Figure 5. Electron microscopic analysis of septate junction formation. Electron micrographs focusing on the CNS blood-brain barrier of late-stage 17 embryos. $\boldsymbol{A}, \boldsymbol{B}$, Wild-type embryo. The boxed area in $\boldsymbol{A}$ is shown in $\boldsymbol{B}$. The subperineurial glial cells (spg) establish prominent electron-dense ladder-like septate junctions (sj, arrowhead). $\boldsymbol{C}, \boldsymbol{D}$, In coiled mutant embryos, no septate junctions can be detected.

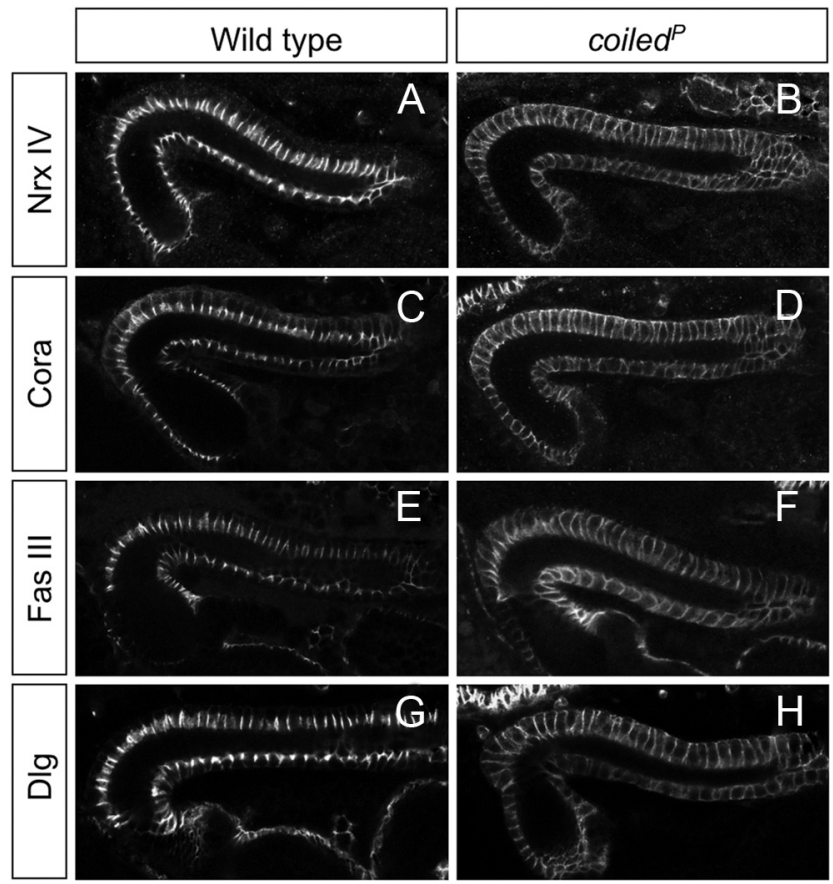

Figure 6. Septate junction proteins are mislocalized in coiled mutants. The figure shows embryonic hindgut from stage 16 wild-type and coiled mutant embryos as indicated. $A$, In the wild type, NeurexinIV (Nrx IV) is localized to a small stretch of the basolateral membrane. $\boldsymbol{B}$, In coiled mutant embryos, the NeurexinlV expression domain expands and is found around the entire cell. A similar expansion of the expression domain was observed for Coracle expression ( $\boldsymbol{C}$, $\boldsymbol{D}$, Cora), Fasciclin III expression ( $\boldsymbol{E}, \boldsymbol{F}$, Fas III), and Discs large expression ( $\mathbf{G}, \boldsymbol{H}, \mathrm{Dlg})$.

nally tagged Coiled protein can rescue the blood-brain barrier defect. When we expressed the protein in the blood-brain-barrierforming subperineurial glial cells together with UAS-CD8-GFP using SPG-Gal4, we noted a very weak expression colocalizing with the general membrane marker (Fig. $9 F-I$ ). During expression of the $\mathrm{N}$-terminally tagged Coiled protein, which is not able to rescue the mutant phenotype, we noted a much stronger labeling, but most of the protein appeared outside the subperineurial glial cells within the nervous system (Fig. 9D,E). Therefore, the N-terminal-tagged protein appears not to be properly attached to the membrane and is thus secreted. Importantly, both the C-terminal and the N-terminal pro- tein are expressed at very similar levels in the blood-brain barrier as shown by Western blot (Fig. 9J). We thus conclude that most of the functional C-terminally tagged Coiled protein is buried in the septate junctions in which it escapes detection by antibodies.

To further test whether membrane anchorage is required for coiled function, we generated a construct encoding a C-terminally tagged Coiled protein lacking the GPIattachment site (Fig. 3). When expressed in S2 cells, this protein is secreted (data not shown). We then generated transgenic flies and inserted the construct in the chromosomal landing site $86 \mathrm{Fb}$. This construct fails to rescue the coiled mutant phenotype. However, the expression of the C-terminally tagged secreted protein was identical to what we found for the C-terminally tagged GPI-anchored Coiled protein (data not shown).

In conclusion, Coiled protein appears integrated into the septate junctions in which it cannot be detected by immunohistochemical methods, although it can easily be detected by Western blots. A secreted Coiled protein can still be incorporated into the cell junctions but is nonfunctional, indicating that Coiled-mediated cell-cell adhesion is relevant for the integrity of the blood-brain barrier.

\section{Discussion}

The Drosophila blood-brain barrier is formed by the subperineurial glial cells, which are interconnected by extensive bands of septate junctions, which prevent uncontrolled paracellular leakage of solutes into the nervous system. To better understand the function of the blood-brain barrier, we undertook a genetic screen looking for mutants in which the barrier function is compromised. Here we report the identification of a small GPI-linked cell-surface protein, Coiled, as a novel component organizing septate junctions in Drosophila.

The BBB is generated during late embryonic stages by the subperineurial glia (Bainton et al., 2005; Schwabe et al., 2005). These cells remain in place until adult stages, and the septate junctions established remain stable over a very long time. Work on the tracheal system and the developing ectoderm has revealed a large number of genes required for the establishment of septate junctions (Fehon et al., 1994; Baumgartner et al., 1996; Behr et al., 2003; Genova and Fehon, 2003; Paul et al., 2003; Schulte et al., 2003; Faivre-Sarrailh et al., 2004; Llimargas et al., 2004; Wu and Beitel, 2004; Wu et al., 2004, 2007; Banerjee et al., 2006a; Furuse and Tsukita, 2006; Hijazi et al., 2009; Nelson et al., 2010; Nilton et al., 2010). To date, $\sim 18$ cell-surface proteins have been described that are all structurally associated with septate junctions. Among these, some mediate homophilic adhesion, such as the GPIlinked protein Lachesin or the Ig-domain protein Fasciclin3, whereas other proteins mediate heterophilic adhesion, such as NeurexinIV or Gliotactin (Bieber et al., 1989; Snow et al., 1989; Auld et al., 1995; Genova and Fehon, 2003; Schulte et al., 2003; Llimargas et al., 2004; Strigini et al., 2006). Interestingly, septate junction organization appears identical in the CNS and other ectodermal derivatives, and, for many septate junction components, a disruption of the blood-brain barrier integrity has been demonstrated. 
Here we have shown that the Ly6 protein family member Coiled mediates homophilic adhesion and is also required for septate junction formation. In line with the morphological results, we determined dye penetration kinetics similar to mutants lacking the $n r x I V$ gene, which is also crucially required for septate junction formation. A GFP-exon trap indicates that Coiled is specifically expressed in the subperineurial glia in which it is enriched in septate junctions. The GFPtagged protein is not functional, and most of it appears to accumulate in the cytoplasm. In contrast, expression of an $\mathrm{N}$-terminally HA-tagged Coiled variant, which is also nonfunctional, becomes secreted and diffuses in the nervous system. When we expressed a C-terminally tagged Coiled protein, we could not easily detect the protein in tissue but in Western blots, suggesting that the C-terminally tagged Coiled protein is masked when integrated in septate junctions. A C-terminally tagged, truncated Coiled variant lacking the GPI anchor, which cannot rescue the mutant coiled phenotype, also appears to be weakly expressed. This indicates that the mutant protein is incorporated into the septate junctions, but as a result of the lack of its GPI anchor, it cannot mediate adhesive functions and is nonfunctional.

Coiled is a member of the Ly6 family characterized by a conserved set of 10 cysteine residues. The $3 \mathrm{D}$ structure of the Ly6/CD59 proteins has been resolved and resembles the one shown by certain snake neurotoxins, which target specific nicotinic acetylcholine receptors (Tsetlin, 1999; Huang et al., 2007). The CD59 protein, a small glycosylated protein, is linked to the plasma membrane via a GPI anchor. A prime function of CD59 is during complement activation, when it inhibits the assembly of the terminal membrane attack complex and thereby prevents damage to "self" cells (Meri et al., 1990). Ly6 proteins are involved in early steps of T-cell-receptormediated T-cell activation (Kimberley et al., 2007). Recent studies provided evidence that Ly6-related proteins mediate cell adhesion and interact with unknown ligands on the antigenpresenting cells, which leads to T-cell suppression (Bamezai and Rock, 1995; Brakenhoff et al., 1995; Hänninen et al., 1997; Holt et al., 2001; Longhi et al., 2005; Kimberley et al., 2007). Interestingly, the human E48 antigen, another member of the Ly6 family, is required in lymphocyte extravasation through the endothelium (Eshel et al., 2002). Interactions of Ly6 protein family members with their target proteins at the plasma membrane may also occur in cis-. This has been observed during the activation of Syk kinase in immune cells or during the modulation of cholinergic receptor function in neurons (Miwa et al., 1999; Halova et al., 2002; Miwa et al., 2006; Choo et al., 2008).

Members of the Ly6 protein family are widely expressed outside the immune system (Blake et al., 1993; Harris et al., 2003; Bamezai, 2004; Papanastasiou et al., 2007). In newts, expression of an Ly6-related molecule called Prod 1 has been linked to regeneration as a marker for local identity (da Silva et al., 2002; Brockes
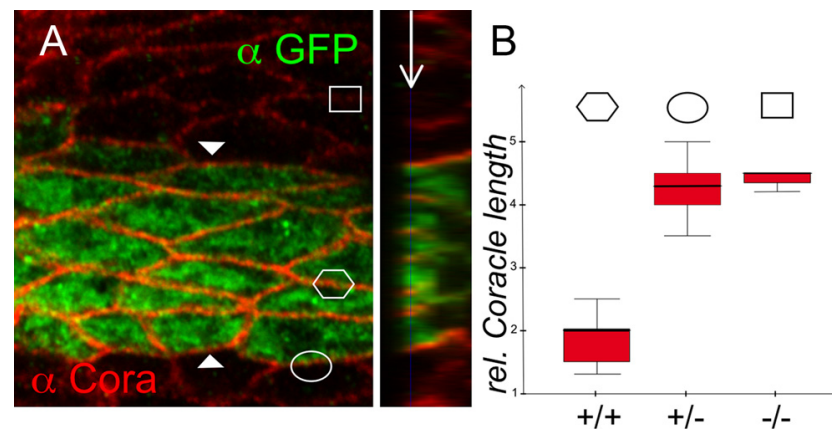

Figure 8. Symmetric Coiled expression is required for septate junction formation. $A$, Frontal view of a single confocal section of a stage 16 mutant coiled embryo expressing Coiled and GFP in the engrailed pattern, stained for Coracle (red) and GFP (green) expression. The plain of view is indicated in the orthogonal section (arrow). The length of septate junctions is rescued to the normal length among cells within the engrailed domain (hexagon), whereas between mutant and rescued cells the Coracle expression domain is expanded as in the mutant tissue (oval and rectangle, respectively). The relative Coracle expression domain length is quantified in $\boldsymbol{B} . n=$ 60 cells. $+/+$ indicates Coracle expression domain length between rescued cells, $+/-$ indicates Coracle expression domain length between rescued and mutant cells, and $-/-$ indicates Coracle expression domain length between two mutant cells.

and Kumar, 2005). Another member of the Ly6 protein family, such as the secreted SLURP-1 protein, which lacks the GPI anchor, has been linked to the skin disorder Mal de Meleda (Fischer et al., 2001). In mammals, recent transcriptome analyses have 

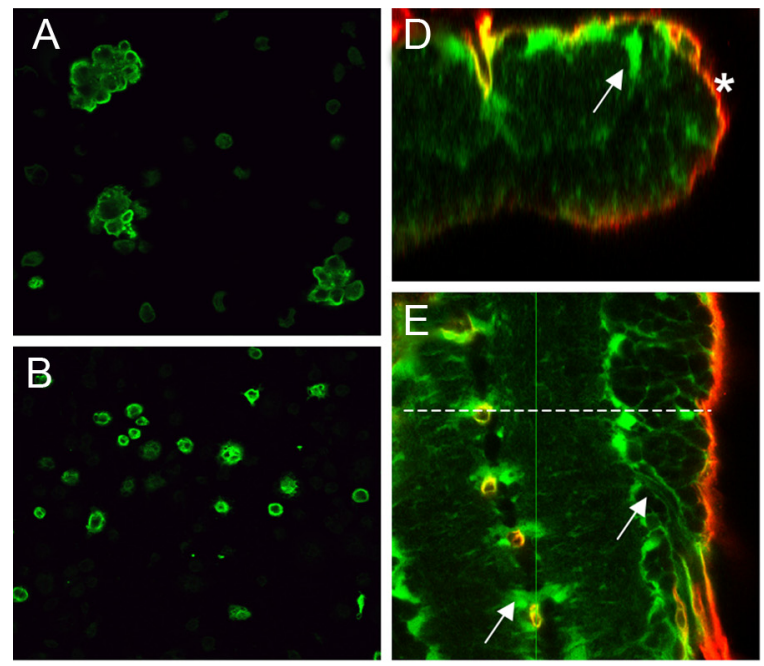

C $J$

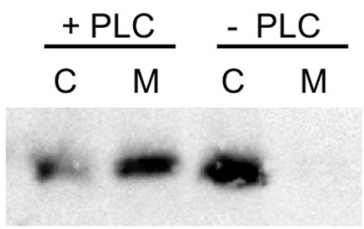

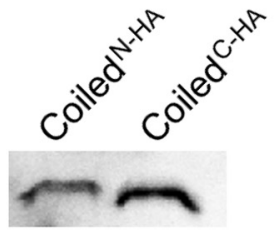
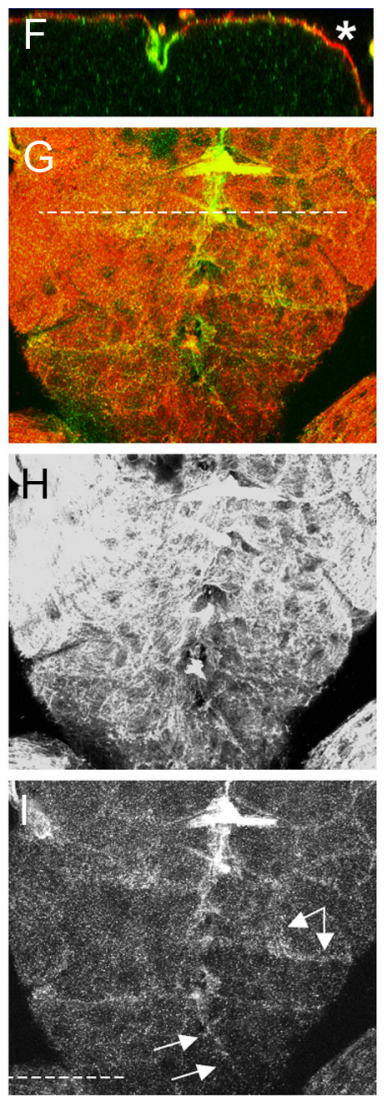

Figure 9. Coiled mediates adhesive functions. S2 cell aggregation assay. $\boldsymbol{A}$, After transfection with C-terminally tagged Coiled, cell aggregates were detected after anti-HA staining (green). B, After transfection with $\mathrm{N}$-terminally tagged Coiled, no cell aggregates are formed. C, Western blot. S2 cells were transfected with a C-terminally tagged Coiled protein. Cell extract (C) and cell culture supernatant $(\mathrm{M})$ were probed with anti-HA antibody. In the presence of PI-PLC, HA-tagged Coiled protein is released into the supernatant. In the absence of PI-PLC, no Coiled protein can be detected in the supernatant. D-I, Confocal sections showing SPGGal4-driven expression of C- or N-terminally tagged Coiled protein and CD8GFP in the ventral nerve cord of third-instar larvae. $D$, Orthogonal section through the nerve cord. The position is indicated by a dashed line in $E$. In animals with the genotype SPGGal4 UASCD8GFPUASCoiled ${ }^{N-\text {-erminal HA }}$, Coiled expression (green) is found outside the moody-positive subperineurial glial cells (asterisk) within the entire nerve cord. The arrow indicates $\mathrm{N}$-terminally tagged Coiled accumulation in areas flanking the neuropil. $F, G$, In animals with the genotype SPGGal4 UASCD8GFP UASCoiled ${ }^{\text {-terminal } H A}$ from the same chromosomal landing sites, only weak Coiled expression (green) is found in the moody-positive subperineurial glial cells (red, asterisk). $\mathbf{G}$, The dashed line indicates the plane of section in the orthogonal section shown in $\boldsymbol{F}$. $\boldsymbol{H}$, Expression of CD8GFP in the moody domain. $\boldsymbol{I}$, Expression of Coiled ${ }^{\text {(-terminal }}{ }^{H A}$ in the moody domain. The arrows indicate Coiled expression at the borders of the subperineurial cells. J, Western blot of embryos expressing $\mathrm{N}$-terminal or C-terminal HA-tagged Coiled protein in all glial cells using the repoGal4 driver strain.

shown that Ly6-like proteins are also expressed by the bloodbrain barrier forming endothelial cells (Daneman et al., 2010).

Surprisingly, the Drosophila genome encodes a similar large number of Ly6 family proteins as the human genome (41 vs 45 family members) (Galat, 2008; Hijazi et al., 2009). The different proteins are thought to exert a large range of molecular functions. The cell-surface protein Sleepless is involved in the control of sleeping behavior, the Retroactive protein is involved in the assembly of tracheal luminal chitin, and the secreted protein Boudin is involved in septate junction formation in the tracheal system (Moussian et al., 2006; Koh et al., 2008; Hijazi et al., 2009; $\mathrm{Wu}$ et al., 2010). As a common denominator, all different Ly6 family members are implicated in the recognition of extracellular cues, ranging from cell adhesion and signal transduction to cell activation processes.

GPI-linked proteins can in principle be localized to internal vesicles or to the plasma membrane. Unfortunately, we were unable to generate specific antibodies to allow the detection of endogenous Coiled expression in tissues. However, the fact that S2 cells transfected with UAScoiled were able to form aggregates and the fact that PI-PLC treatment resulted in the shedding of Coiled into the cell supernatant suggest that Coiled is indeed a cellsurface protein, as has been demonstrated for many other members of the Ly6 family (see above). The closely related Boudin protein shows a broad cellular distribution and can act non-autonomously on septate junction formation (Hijazi et al., 2009).

Coiled is crucially required for the formation of septate junctions among subperineurial glial cells. A core component of the Drosophila septate junction is NeurexinIV whose expression requires differential splicing (Baumgartner et al., 1996; Stork et al., 2009). Correct membrane localization of NeurexinIV is brought about by the GPI-linked protein Contactin. Surprisingly, loss of Contactin is relatively well tolerated, and the BBB is only moderately affected (Faivre-Sarrailh et al., 2004). Recently, it was suggested that Coiled is also required for the correct trafficking of NeurexinIV, and Coiled was reported to exhibit a vesicular expression within cells (Nilton et al., 2010). This vesicular distribution may reflect recycling Coiled protein because membrane expression appears rather low. Based on the PI-PLC treatment and the cell aggregation experiments, we propose that Coiled acts primarily at the cell surface. In line with this notion, a secreted, full-length $\mathrm{N}$-terminally tagged Coiled protein cannot rescue the blood-brain barrier phenotype. In addition, it is interesting to note that the secreted Coiled protein does not appear to distribute in a random manner throughout the nervous system but rather appears to associate with other glial cells. Thus, either cortex and neuropil glial cells specifically phagocytose the Coiled protein or express a yet unknown Coiled receptor, possibly another member of the Ly6 family (Hijazi et al., 2009). The function of Coiled could therefore provide adhesiveness to prime the formation of septate junctions and to allow the subsequent integration of the NeurexinIV-based adhesive system. How Coiled and possibly other Ly6 domain proteins stabilize NeurexinIV to structure septate junctions must be addressed in future experiments.

\section{References}

Abbott NJ, Rönnbäck L, Hansson E (2006) Astrocyte-endothelial interactions at the blood-brain barrier. Nat Rev Neurosci 7:41-53.

Auld VJ, Fetter RD, Broadie K, Goodman CS (1995) Gliotactin, a novel transmembrane protein on peripheral glia, is required to form the bloodnerve barrier in Drosophila. Cell 81:757-767.

Awasaki T, Lai SL, Ito K, Lee T (2008) Organization and postembryonic development of glial cells in the adult central brain of Drosophila. J Neurosci 28:13742-13753.

Bachmann A, Draga M, Grawe F, Knust E (2008) On the role of the MAGUK 
proteins encoded by Drosophila varicose during embryonic and postembryonic development. BMC Dev Biol 8:55.

Bainton RJ, Tsai LT, Schwabe T, DeSalvo M, Gaul U, Heberlein U (2005) moody encodes two GPCRs that regulate cocaine behaviors and bloodbrain barrier permeability in Drosophila. Cell 123:145-156.

Bamezai A (2004) Mouse Ly-6 proteins and their extended family: markers of cell differentiation and regulators of cell signaling. Arch Immunol Ther Exp (Warsz) 52:255-266.

Bamezai A, Rock KL (1995) Overexpressed Ly-6A. 2 mediates cell-cell adhesion by binding a ligand expressed on lymphoid cells. Proc Natl Acad Sci U S A 92:4294-4298.

Banerjee S, Bhat MA (2007) Neuron-glial interactions in blood-brain barrier formation. Annu Rev Neurosci 30:235-258.

Banerjee S, Sousa AD, Bhat MA (2006a) Organization and function of septate junctions: an evolutionary perspective. Cell Biochem Biophys 46:65-77.

Banerjee S, Pillai AM, Paik R, Li J, Bhat MA (2006b) Axonal ensheathment and septate junction formation in the peripheral nervous system of Drosophila. J Neurosci 26:3319-3329.

Baumgartner S, Littleton JT, Broadie K, Bhat MA, Harbecke R, Lengyel JA, Chiquet-Ehrismann R, Prokop A, Bellen HJ (1996) A Drosophila neurexin is required for septate junction and blood-nerve barrier formation and function. Cell 87:1059-1068.

Behr M, Riedel D, Schuh R (2003) The claudin-like megatrachea is essential in septate junctions for the epithelial barrier function in Drosophila. Dev Cell 5:611-620.

Bhat MA, Rios JC, Lu Y, Garcia-Fresco GP, Ching W, St Martin M, Li J, Einheber S, Chesler M, Rosenbluth J, Salzer JL, Bellen HJ (2001) Axonglia interactions and the domain organization of myelinated axons requires neurexin IV/Caspr/Paranodin. Neuron 30:369-383.

Bieber AJ, Snow PM, Hortsch M, Patel NH, Jacobs JR, Traquina ZR, Schilling J, Goodman CS (1989) Drosophila neuroglian: a member of the immunoglobulin superfamily with extensive homology to the vertebrate neural adhesion molecule L1. Cell 59:447-460.

Bischof J, Maeda RK, Hediger M, Karch F, Basler K (2007) An optimized transgenesis system for Drosophila using germ-line-specific phiC31 integrases. Proc Natl Acad Sci U S A 104:3312-3317.

Blake PG, Madrenas J, Halloran PF (1993) Ly-6 in kidney is widely expressed on tubular epithelium and vascular endothelium and is upregulated by interferon gamma. J Am Soc Nephrol 4:1140-1150.

Brakenhoff RH, Gerretsen M, Knippels EM, van Dijk M, van Essen H, Weghuis DO, Sinke RJ, Snow GB, van Dongen GA (1995) The human E48 antigen, highly homologous to the murine Ly- 6 antigen ThB, is a GPIanchored molecule apparently involved in keratinocyte cell-cell adhesion. J Cell Biol 129:1677-1689.

Brockes JP, Kumar A (2005) Appendage regeneration in adult vertebrates and implications for regenerative medicine. Science 310:1919-1923.

Carlson SD, Juang JL, Hilgers SL, Garment MB (2000) Blood barriers of the insect. Annu Rev Entomol 45:151-174.

Choo YM, Lee BH, Lee KS, Kim BY, Li J, Kim JG, Lee JH, Sohn HD, Nah SY, Jin BR (2008) Pr-lynx1, a modulator of nicotinic acetylcholine receptors in the insect. Mol Cell Neurosci 38:224-235.

da Silva SM, Gates PB, Brockes JP (2002) The newt ortholog of CD59 is implicated in proximodistal identity during amphibian limb regeneration. Dev Cell 3:547-555.

Daneman R, Barres BA (2005) The blood-brain barrier: lessons from moody flies. Cell 123:9-12.

Daneman R, Zhou L, Agalliu D, Cahoy JD, Kaushal A, Barres BA (2010) The mouse blood-brain barrier transcriptome: a new resource for understanding the development and function of brain endothelial cells. PLoS One 5:e13741.

Dowell RD, Jokerst RM, Day A, Eddy SR, Stein L (2001) The distributed annotation system. BMC Bioinform 2:7.

Edenfeld G, Stork T, Klämbt C (2005) Neuron-glia interaction in the insect nervous system. Curr Opin Neurobiol 15:34-39.

Edwards TN, Meinertzhagen IA (2010) The functional organisation of glia in the adult brain of Drosophila and other insects. Prog Neurobiol 90:471-497.

Eshel R, Zanin A, Kapon D, Sagi-Assif O, Brakenhoff R, van Dongen G, Witz IP (2002) Human Ly-6 antigen E48 (Ly-6D) regulates important interaction parameters between endothelial cells and head-and-neck squamous carcinoma cells. Int J Cancer 98:803-810.
Faivre-Sarrailh C, Banerjee S, Li J, Hortsch M, Laval M, Bhat MA (2004) Drosophila contactin, a homolog of vertebrate contactin, is required for septate junction organization and paracellular barrier function. Development 131:4931-4942.

Fehon RG, Dawson IA, Artavanis-Tsakonas S (1994) A Drosophila homologue of membrane-skeleton protein 4.1 is associated with septate junctions and is encoded by the coracle gene. Development 120:545-557.

Fischer J, Bouadjar B, Heilig R, Huber M, Lefèvre C, Jobard F, Macari F, Bakija-Konsuo A, Ait-Belkacem F, Weissenbach J, Lathrop M, Hohl D, Prud'homme JF (2001) Mutations in the gene encoding SLURP-1 in Mal de Meleda. Hum Mol Genet 10:875-880.

Furuse M, Tsukita S (2006) Claudins in occluding junctions of humans and flies. Trends Cell Biol 16:181-188.

Galat A (2008) The three-fingered protein domain of the human genome. Cell Mol Life Sci 65:3481-3493.

Genova JL, Fehon RG (2003) Neuroglian, Gliotactin, and the $\mathrm{Na}^{+} / \mathrm{K}^{+} \mathrm{AT}-$ Pase are essential for septate junction function in Drosophila. J Cell Biol 161:979-989.

Girault JA, Peles E (2002) Development of nodes of Ranvier. Curr Opin Neurobiol 12:476-485.

Hahn M, Jäckle H (1996) Drosophila goosecoid participates in neural development but not in body axis formation. EMBO J 15:3077-3084.

Hálová I, Dráberová L, Dráber P (2002) A novel lipid raft-associated glycoprotein, TEC-21, activates rat basophilic leukemia cells independently of the type 1 Fc epsilon receptor. Int Immunol 14:213-223.

Hänninen A, Jaakkola I, Salmi M, Simell O, Jalkanen S (1997) Ly-6C regulates endothelial adhesion and homing of $\mathrm{CD} 8(+) \mathrm{T}$ cells by activating integrin-dependent adhesion pathways. Proc Natl Acad Sci USA 94:6898-6903.

Harris CL, Hanna SM, Mizuno M, Holt DS, Marchbank KJ, Morgan BP (2003) Characterization of the mouse analogues of CD59 using novel monoclonal antibodies: tissue distribution and functional comparison. Immunology 109:117-126.

Hijazi A, Masson W, Augé B, Waltzer L, Haenlin M, Roch F (2009) boudin is required for septate junction organisation in Drosophila and codes for a diffusible protein of the Ly6 superfamily. Development 136:2199-2209.

Holt DS, Botto M, Bygrave AE, Hanna SM, Walport MJ, Morgan BP (2001) Targeted deletion of the CD59 gene causes spontaneous intravascular hemolysis and hemoglobinuria. Blood 98:442-449.

Huang Y, Fedarovich A, Tomlinson S, Davies C (2007) Crystal structure of CD59: implications for molecular recognition of the complement proteins C8 and C9 in the membrane-attack complex. Acta Crystallogr D Biol Crystallogr 63:714-721.

Ito K, Urban J, Technau GM (1995) Distribution, classification, and development of Drosophila glial cells in the late embryonic and early larval ventral nerve cord. Roux's Arch Dev Biol 204:284-307.

Kimberley FC, Sivasankar B, Paul Morgan B (2007) Alternative roles for CD59. Mol Immunol 44:73-81.

Klämbt C, Goodman CS (1991) The diversity and pattern of glia during axon pathway formation in the Drosophila embryo. Glia 4:205-213.

Koh K, Joiner WJ, Wu MN, Yue Z, Smith CJ, Sehgal A (2008) Identification of SLEEPLESS, a sleep-promoting factor. Science 321:372-376.

Krans JL, Parfitt KD, Gawera KD, Rivlin PK, Hoy RR (2010) The resting membrane potential of Drosophila melanogaster larval muscle depends strongly on external calcium concentration. J Insect Physiol 56:304-313.

Lamb RS, Ward RE, Schweizer L, Fehon RG (1998) Drosophila coracle, a member of the protein 4.1 superfamily, has essential structural functions in the septate junctions and developmental functions in embryonic and adult epithelial cells. Mol Biol Cell 9:3505-3519.

Laprise P, Lau KM, Harris KP, Silva-Gagliardi NF, Paul SM, Beronja S, Beitel GJ, McGlade CJ, Tepass U (2009) Yurt, Coracle, Neurexin IV and the $\mathrm{Na}(+), \mathrm{K}(+)$-ATPase form a novel group of epithelial polarity proteins. Nature 459:1141-1145.

Laprise P, Paul SM, Boulanger J, Robbins RM, Beitel GJ, Tepass U (2010) Epithelial polarity proteins regulate Drosophila tracheal tube size in parallel to the luminal matrix pathway. Curr Biol 20:55-61.

Llimargas M, Strigini M, Katidou M, Karagogeos D, Casanova J (2004) Lachesin is a component of a septate junction-based mechanism that controls tube size and epithelial integrity in the Drosophila tracheal system. Development 131:181-190.

Longhi MP, Sivasankar B, Omidvar N, Morgan BP, Gallimore A (2005) 
Cutting edge: murine CD59a modulates antiviral CD4 + T cell activity in a complement-independent manner. J Immunol 175:7098-7102.

Mayer F, Mayer N, Chinn L, Pinsonneault RL, Kroetz D, Bainton RJ (2009) Evolutionary conservation of vertebrate blood-brain barrier chemoprotective mechanisms in Drosophila. J Neurosci 29:3538-3550.

Meri S, Morgan BP, Davies A, Daniels RH, Olavesen MG, Waldmann H, Lachmann PJ (1990) Human protectin (CD59), an 18,000-20,000 MW complement lysis restricting factor, inhibits C5b-8 catalysed insertion of C9 into lipid bilayers. Immunology 71:1-9.

Miwa JM, Ibanez-Tallon I, Crabtree GW, Sánchez R, Sali A, Role LW, Heintz N (1999) lynx1, an endogenous toxin-like modulator of nicotinic acetylcholine receptors in the mammalian CNS. Neuron 23:105-114.

Miwa JM, Stevens TR, King SL, Caldarone BJ, Ibanez-Tallon I, Xiao C, Fitzsimonds RM, Pavlides C, Lester HA, Picciotto MR, Heintz N (2006) The prototoxin lynx 1 acts on nicotinic acetylcholine receptors to balance neuronal activity and survival in vivo. Neuron 51:587-600.

Moussian B, Tång E, Tonning A, Helms S, Schwarz H, Nüsslein-Volhard C, Uv AE (2006) Drosophila Knickkopf and Retroactive are needed for epithelial tube growth and cuticle differentiation through their specific requirement for chitin filament organization. Development 133:163-171.

Nelson KS, Furuse M, Beitel GJ (2010) The Drosophila Claudin Kune-kune is required for septate junction organization and tracheal tube size control. Genetics 185:831-839.

Nilton A, Oshima K, Zare F, Byri S, Nannmark U, Nyberg KG, Fehon RG, Uv AE (2010) Crooked, coiled and crimpled are three Ly6-like proteins required for proper localization of septate junction components. Development 137:2427-2437.

Papanastasiou AD, Georgaka E, Zarkadis IK (2007) Cloning of a CD59-like gene in rainbow trout. Expression and phylogenetic analysis of two isoforms. Mol Immunol 44:1300-1306.

Paul SM, Ternet M, Salvaterra PM, Beitel GJ (2003) The Na +/K+ ATPase is required for septate junction function and epithelial tube-size control in the Drosophila tracheal system. Development 130:4963-4974.

Pereanu W, Shy D, Hartenstein V (2005) Morphogenesis and proliferation of the larval brain glia in Drosophila. Dev Biol 283:191-203.

Poliak S, Peles E (2003) The local differentiation of myelinated axons at nodes of Ranvier. Nat Rev Neurosci 4:968-980.

Royet J, Bouwmeester T, Cohen SM (1998) Notchless encodes a novel WD40-repeat-containing protein that modulates Notch signaling activity. EMBO J 17:7351-7360.

Salzer JL, Brophy PJ, Peles E (2008) Molecular domains of myelinated axons in the peripheral nervous system. Glia 56:1532-1540.

Schulte J, Tepass U, Auld VJ (2003) Gliotactin, a novel marker of tricellular junctions, is necessary for septate junction development in Drosophila. J Cell Biol 161:991-1000.

Schwabe T, Bainton RJ, Fetter RD, Heberlein U, Gaul U (2005) GPCR signaling is required for blood-brain barrier formation in Drosophila. Cell 123:133-144
Silies M, Yuva Y, Engelen D, Aho A, Stork T, Klämbt C (2007) Glial cell migration in the eye disc. J Neurosci 27:13130-13139.

Snow PM, Bieber AJ, Goodman CS (1989) Fasciclin III: a novel homophilic adhesion molecule in Drosophila. Cell 59:313-323.

Stork T, Engelen D, Krudewig A, Silies M, Bainton RJ, Klämbt C (2008) Organization and function of the blood-brain barrier in Drosophila. J Neurosci 28:587-597.

Stork T, Thomas S, Rodrigues F, Silies M, Naffin E, Wenderdel S, Klämbt C (2009) Drosophila Neurexin IV stabilizes neuron-glia interactions at the CNS midline by binding to Wrapper. Development 136:1251-1261.

Strigini M, Cantera R, Morin X, Bastiani MJ, Bate M, Karagogeos D (2006) The IgLON protein Lachesin is required for the blood-brain barrier in Drosophila. Mol Cell Neurosci 32:91-101.

Tepass U, Hartenstein V (1994) The development of cellular junctions in the Drosophila embryo. Dev Biol 161:563-596.

Tomancak P, Berman BP, Beaton A, Weiszmann R, Kwan E, Hartenstein V, Celniker SE, Rubin GM (2007) Global analysis of patterns of gene expression during Drosophila embryogenesis. Genome Biol 8:R145.

Tsetlin V (1999) Snake venom alpha-neurotoxins and other "three-finger" proteins. Eur J Biochem 264:281-286.

Tweedie S, Ashburner M, Falls K, Leyland P, McQuilton P, Marygold S, Millburn G, Osumi-Sutherland D, Schroeder A, Seal R, Zhang H; FlyBase Consortium (2009) FlyBase: enhancing Drosophila Gene Ontology annotations. Nucleic Acids Res 37:D555-D559.

Volwerk JJ, Koke JA, Wetherwax PB, Griffith OH (1989) Functional characteristics of phosphatidylinositol-specific phospholipases C from Bacillus cereus and Bacillus thuringiensis. FEMS Microbiol Lett 52:237-241.

Woods DF, Bryant PJ (1991) The discs-large tumor suppressor gene of Drosophila encodes a guanylate kinase homolog localized at septate junctions. Cell 66:451-464.

Wu MN, Joiner WJ, Dean T, Yue Z, Smith CJ, Chen D, Hoshi T, Sehgal A, Koh K (2010) SLEEPLESS, a Ly-6/neurotoxin family member, regulates the levels, localization and activity of Shaker. Nat Neurosci 13:69-75.

Wu VM, Beitel GJ (2004) A junctional problem of apical proportions: epithelial tube-size control by septate junctions in the Drosophila tracheal system. Curr Opin Cell Biol 16:493-499.

Wu VM, Schulte J, Hirschi A, Tepass U, Beitel GJ (2004) Sinuous is a Drosophila claudin required for septate junction organization and epithelial tube size control. J Cell Biol 164:313-323.

Wu VM, Yu MH, Paik R, Banerjee S, Liang Z, Paul SM, Bhat MA, Beitel GJ (2007) Drosophila Varicose, a member of a new subgroup of basolateral MAGUKs, is required for septate junctions and tracheal morphogenesis. Development 134:999-1009.

Younossi-Hartenstein A, Salvaterra PM, Hartenstein V (2003) Early development of the Drosophila brain. IV. Larval neuropile compartments defined by glial septa. J Comp Neurol 455:435-450.

Zlokovic BV (2008) The blood-brain barrier in health and chronic neurodegenerative disorders. Neuron 57:178-201. 